\title{
Brexit and Nurse education
}

On June 23 2016, the British public voted to exit the European Union. Whilst nurses tend not to be political animals, the result of the referendum has certainly caught many by surprise. The result has sparked a real sense of unrest among the people, and instilled a sense of rejection of our European colleagues, unsettling collaborations which have built up over the past 40 years, but it has also spun our political leaders into a state of crisis (Niblett 2016). It is our political leaders who, after all, are in the position of negotiating the terms of our exit. What will this mean for the flow of nursing staff and students from Europe, the structure of the pre-registration curriculum and the opportunities post qualifying to travel and work in Europe?

Keogh and Flynn (2016) acknowledge from Health and Social Care Information Centre that the NHS in England is supported by over 21,000 registered nurses and health visitors from the EU, $7 \%$ of the total workforce, with many more EU support workers both in the NHS and care homes (Scott 2016). Indeed, Munro (2016) confirms that more than two-thirds of NHS Trusts are still actively recruiting from the European Union. My senior nursing colleagues in practice advise that in spite of their initial struggle to adopt the nuances of local colloquialisms as they master the English language, European nurses offer a 'value added' with considerable advanced skills and caring attitudes. Additionally, they tend to remain in post actively supporting the vision and mission of their organisation. They are a real boost to the functioning of our NHS.

In truth, no-one knows what the impact of Brexit will mean for nursing and nurse education and all will depend on whether we exit fully from the single market. However, this will not be immediate and is dependent on the Government triggering exit negotiations set out under Article 50 of the Lisbon Treaty with the specified period for negotiations being two years. Whatever arises from this agreement, it may be that both prospective students and NHS staff from across the EU will not be recognised and that EU nurses will be treated the same as those external to Europe and be required to adhere to the strict immigration requirements currently in operation. In my experience, most UK universities attract a significant number of EU students and staff. Unless the negotiations permit a deal that will allow Europeans to enter the UK without going through the rigorous immigration requirements, any downturn in recruitment and retaining sufficient numbers of students and staff will seriously affect the current financial model and the stability of the workforce for both universities and the NHS. This means that we will need to recruit an increased number of new nursing students to reach the level of workforce necessary for organisations to function. However, it is well known that the capacity of the NHS to support placements for student nurses is pretty much at maximum. So, we need to do much to encourage student recruitment at a time when the funding arrangements require student nurses and other healthcare professionals to fund themselves by accessing student loans in September 2017.

The requirements for nursing education, certainly for the field of Adult nurses require Adult field nurses to complete 2,300 hours in both theory and practice. Perhaps our choice to exit Europe will trigger a move to purely competency based outcomes rather than adhere to the current focus on hours completed? The EU directive 2013/55/EU (Kyrieri 2014) dictates the length of the programme, the content, the ratio of theory to practice, the nature of practice learning and the range of experience to abide by the European standard. Although nothing is likely to change at present, the NMC will need to reconsider once negotiations are complete. 
From a university perspective, the UK benefits considerably from European research funding, as well as the development and growth of partnerships and collaborations between our European colleagues in the research endeavour. Dyke (2016) suggests that Horizon 2020 supported NHS providers with $£ 232 \mathrm{~m}$ research, development and innovation last year and McKenna (2016) reinforced the concern about the future of science and research due to the potential for reducing the free movement of researchers across Europe and the inability to access European research funding. Additionally, many of our health, safety and employment rights are governed by European law eg the European working time directive.

Whatever our concerns, the focus will now be on negotiating the best deal for the UK after our exit, particularly on trade and working with the EU. However, the myriad of policies, laws as well as ultimately the opportunities for nurses once they qualify to work and travel may be vastly different to what we are currently accustomed to.

Dyke, M. (2016) The NHS, how Brexit could affect our health service. Trade Union Centre (TUC). Accessed on 1.7.16 at https://www.tuc.org.uk/sites/default/files/brexit-TheNHS2.pdf

Kyrieri, K-M (2014) The Modernised Directive on Professional Qualifications and its Impact on National Legislations. [EU Directive 2013/55/EU]. Accessed on 5.7.16 at http://www.eipa.eu/files/repository/eipascope/20141120090725 EIPASCOPE 2014 KKY.pd

Keogh, K. \& Flynn, H. (2016) Chief nurse reassured EU workers after Brexit vote. Nursing Standard, 30(44), 7.

McKenna, H. (2016) Five big issues for health and social care after the Brexit voted. The Kings Fund. Accessed on 1.7.16 at http://www.kingsfund.org.uk/publications/articles/brexitand-nhs\#top

Munro, A. (2016) Should we stay or should we go? What would Brexit mean for nurses? Journal of Community Nursing, 30(3), 16.

Niblett, R. (2016) Brexit the reality. Chatham House. $24^{\text {th }}$ June. Accessed on 1.7 .16 at https://www.chathamhouse.org/expert/comment/brexitreality?gclid=CjwKEAjwqdi7BRCL6Zmjk5rsTwSJABmrVabtyt3LnQP0801ySFKGntz5UOYDAUtgMXXtkesWVVACRoC5Nbw wcB

Scott, G. (2016) (editorial) Brexit what are the implications for nurses? Nursing Standard. Accessed on 1.7.16 at http://journals.rcni.com/doi/pdfplus/10.7748/ns.30.44.3.s1 